\title{
PREVENTION IS BETTER THAN CURE: EXPERIMENTAL EVIDENCE FROM MILK FEVER INCIDENCE IN DAIRY ANIMALS OF HARYANA, INDIA
}

A. G. Adeeth Cariappa*1, B. S. Chandel ${ }^{1}$, Gopal Sankhala ${ }^{2}$, Veena Mani ${ }^{3}$, Sendhil $\mathrm{R}^{4}$, Anil Kumar Dixit ${ }^{1}$ and B. S. Meena ${ }^{2}$

\section{ABSTRACT}

Calcium deficiency in high yielding bovines during calving causes "milk fever" which leads to economic losses of around ₹ 1,000 crores (US \$ 137 million) per annum in Haryana, India. With increasing milk production, the risk of milk fever is continuously rising. In the context, we aim to address the most fundamental research question: What is the effect of a preventive health product (anionic mineral mixture (AMM)) on milk fever incidence, milk productivity and farmers' income? In an effort to contribute to the scanty economic literature on effect of preventive measures on nutritional deficiency disorders in dairy animals, specifically, on AMM effects in India, this study uses a randomized controlled design to estimate internally valid estimates. Using data from 200 dairy farms, results indicate that milk fever incidence decreases from $21 \%$ at baseline to $2 \%$ in treated animals at followup. Further, AMM leads to a $12 \%$ and $38 \%$ increase in milk yield and farmer's net income, respectively. Profits earned due to the prevention of milk fever [₹ 16,000 (US\$ 218.7)] overweighs the losses from milk fever [₹ 4,000 (US\$ 54.7)]; thus, prevention using AMM is better than cure.

KEYWORDS Milk fever; anionic mineral mixture; randomized controlled trial; impact evaluation; farmers' income; dairy

\section{JEL codes Q10, Q120, Q180, C93}

\footnotetext{
${ }^{1}$ Division of Dairy Economics, Statistics and Management, ICAR-National Dairy Research Institute (ICARNDRI), Karnal - 132001 (Haryana), India.

* Correspondence: adeeth07@gmail.com

${ }^{2}$ Division of Dairy Extension, ICAR-NDRI - 132001 (Haryana), India

${ }^{3}$ Division of Animal Nutrition, ICAR-NDRI - 132001 (Haryana), India

${ }^{4}$ ICAR-Indian Institute of Wheat and Barley Research, Karnal - 132001 (Haryana), India
} 


\section{INTRODUCTION}

Nutritional deficiency disorders in dairy animals and the damages associated with it are avoidable depletion of scarce resources (Thirunavukkarasu et al. 2010). Economic implications of these have assumed increased significance with rapid commercialization and intensification of dairy farming in India. Nutritional deficiency disorders (like calcium or magnesium deficiency) affect the productive and reproductive performance of dairy animals causing economic losses to farmers. Increased loss of milk due to nutritional disorders leads to decreased availability and increased purchase costs to consumers threatening nutritional security of the producers (Hogeveen, Steeneveld and Wolf 2019; Jodlowski et al. 2016; Nilsson et al. 2019). Economic literature provides evidence on the spread and persistence of bacterial and viral dairy animal diseases (Hayer et al. 2017; Sok and Fischer 2020), losses associated with it (Gohin and Rault 2013; Govindaraj et al. 2017; Govindaraj et al. 2021; Boisvert, Kay and Turvey 2012; Barratt et al. 2018) and the control/prevention strategies (Chi et al. 2002; Rich and Winter-Nelson 2007; Hennessy 2007; Rich, Rolandholst and Otte 2014; Fadiga and Katjiuongua 2014; Wang and Hennessy 2015; Schroeder et al. 2015; Krieger et al. 2017; Wang and Hennessy 2014). However, evidence on the economic effects of prevention of nutritional deficiency disorders is absent.

Milk fever (MF), hypocalcemia, is one such metabolic illness in dairy animals. It is the decrease in blood calcium (Ca) level due to rapid drain of 
Ca into colostrum after parturition (calving) (Melendez and Poock 2017; Rodríguez, Arís and Bach 2017). As Ca is essential for organs which has smooth muscle functions like uterus, abomasum, teat sphincter and rumen; the deficiency of $\mathrm{Ca}$ or $\mathrm{MF}$ affects these organs hampering fertility and productive performance (Melendez et al. 2019; Caixeta et al. 2017). MF also leads to immune suppression which makes animals susceptible to economically important diseases like mastitis (Kimura, Reinhardt and Goff 2006). The risk of other metabolic disorders like dystocia, uterine prolapse, retained fetal membranes, ketosis, metritis, etc increases with the presence of MF (Goff 2008; Reinhardt et al. 2011; Melendez and Poock 2017; Oetzel and Miller 2012).

MF is economically important as the incidence, and thus losses, increases with age; in the USA, MF incidence ranges from $25 \%$ to $42 \%$ in $1^{\text {st }}$ to $6^{\text {th }}$ lactation animals (Reinhardt et al. 2011). In India, data on MF incidence is scanty and poorly recorded at the national level. However, three surveys documented the incidence to be $11-12 \%$ in north-eastern states (Paul, Chandel and Ray 2013), 13-14\% in Tamil Nadu (Thirunavukkarasu et al. 2010) and $10 \%$ in Himachal Pradesh (Thakur et al. 2017). The losses due to MF in Tamil Nadu was estimated at around ₹ 41 crores (US\$ 5.4 million) during 2005-08 (Thirunavukkarasu et al. 2010). It was estimated it to be around US\$ 137 million (in high risk animals) during 2020 in Haryana (Cariappa et al. 2021). 
MF prevention is therefore indispensible for the success of reproductive and productive performance of dairy animals Melendez and Poock (2017) and also from the economic point of view (Cariappa et al. 2021). We can avoid loss in milk production and enhance farmers' income by preventing MF, which ensures food and nutritional security of the dairy farmers. It assumes paramount importance now as nutritional outcomes are deteriorating evident in the fall of India's rank in Global Hunger Index ${ }^{5}$.

Although metabolic disorders are a result of complex interactions between risk factors, it can be prevented by the right management decisions (Krieger et al. 2017). Blanc et al. (2014) discusses various approaches available for preventing the MF; the first is feeding anionic salts (negative dietary cationanion difference) before parturition and second, oral or intravenous $\mathrm{Ca}$ supplementation instantly after calving. Benefits of the latter require further investigation as the evidence supporting it is not conclusive (Blanc et al. 2014). The dietary cation-anion difference (DCAD) of dairy animals was originally manipulated to combat the MF (Ender, Dishington and Helgebostad 1971; Block 1984; Delaquis and Block 1995; Iwaniuk and Erdman 2015). Several meta-analysis and systemic reviews of experiments conclude that feeding anionic feed (negative DCAD) pre-partum improves $\mathrm{Ca}$ concentration and reduces MF while improving reproductive and productive performance of dairy animals (Oetzel 1991; Lean et al. 2006; Charbonneau,

\footnotetext{
${ }^{5}$ https://www.globalhungerindex.org/india.html
} 
Pellerin and Oetzel 2006; Santos et al. 2019; Lean et al. 2019). A very few studies beg to differ from these conclusions (Ramos-Nieves et al. 2009).

In 2016, the Indian Council of Agricultural Research-National Dairy Research Institute (ICAR-NDRI), developed and commercialized an 'anionic mineral mixture' to prevent $\mathrm{MF}$ in dairy animals ${ }^{6}$. Till date, except an observational study by Thakur et al. (2017), there is no study that evaluates the effect of anionic diets on animal health or production parameters outside the controlled setting of experimental farms of Indian research institutes. Thakur et al. (2017) observed that the MF incidence decreases from $10 \%$ in non-users to $2.5 \%$ in users of anionic diets; milk yield improvement was observed in $60 \%$ (in 24 out of 40 animals) and $45 \%$ of the animals in user and non-user group respectively. However, the study did not quantify the level of yield improvement.

In this study, we go beyond primary trials in research institutes and observational studies. Our work is set in five villages of Haryana State, Northern India with 200 animals from 200 dairy farms (100 cows and 100 buffaloes). In an effort to produce internally valid estimates, we use a randomized controlled design to conduct a household level analysis of the effect of feeding anionic diets to prevent $\mathrm{MF}$ in farmers' field. We complement the vast literature to include the economic effects on selfreported incidence of MF, milk yield, fat-corrected milk yield and farmer's

\footnotetext{
${ }^{6}$ https://kamdhenufeeds.com/product/anionic-mishran/ http://ndri.res.in/technologies-patents/
} 
income. We show that AMM is an effective strategy in preventing MF and increasing milk productivity and farmers' net return.

The following section describes the intervention followed by study and intervention design. The next section outlines our data and sample characteristics followed by balance test results. The estimation strategy is detailed after that. Finally, we report and discuss our impact estimates before concluding the study.

\section{INTERVENTION}

The 'Anionic Mineral Mixture' (AMM) is designed to reduce MF and other post-partum problems in cows and buffaloes. The technology along with anions contains Vitamin E, useful against oxidative stress in the pregnant cows which makes it resistant to metabolic disorders and increases reproductive performance ${ }^{7}$. The supplementation of AMM is said to benefit the dairy farmers economically by improving the milk yield (by 10\%), fat content of the milk and the immunity of the animals apart from preventing various diseases ${ }^{8}$. The AMM contains $7640 \mathrm{mEq}$ and $5080 \mathrm{mEq}$ anionic value of sulphur and chloride, respectively; $1340 \mathrm{mEq}$ cationic value of potassium with a total negative dietary cationic anionic difference (DCAD) of $11,380 \mathrm{mEq}$ and $10,000 \mathrm{IU} / \mathrm{kg}$ of Vitamin E. 50 grams each in the morning

\footnotetext{
${ }^{7}$ See Appendix 1 on how AMM causes decrease in MF incidence and increase in productive and reproductive performance of dairy animals.

${ }^{8}$ https://kamdhenufeeds.com/product/anionic-mishran/
} 
and evening before 3-4 weeks of calving is the recommended dosage of AMM feeding.

\section{Study design}

We begin with the sample size determination using statistical power calculations. This is based on one of the primary outcomes - milk yield per animal per day - as registered in the pre-analysis plan ${ }^{9}$. Due to unavailability of data on the other primary outcome - incidence of MF power calculations were done only based on the milk yield. These calculations are designed to give an $80 \%$ chance to correctly detect the effect when there is an effect (power), with $5 \%$ level of significance. Data on mean of milk yield in rural Haryana is obtained from Indiastat database ${ }^{10}$ and standard deviation is taken from a survey conducted by (Lal et al. 2020). Using the above parameters and an assumed $\mathrm{R}^{2}$ of 0.5 in the final impact regression ${ }^{11}$, a minimum total sample size of 172 animals was required to detect a statistically significant effect of $10 \%$ increase in milk yield between treated and control groups. To account for the possibility of attrition, a sample of 200 animals (100 cows and 100 buffaloes) with 100 in treatment (50 cows and 50 buffaloes) and 100 in control (50 cows and 50 buffaloes) were included. Additional 14 animals were sampled, in case of replacement. Note that 200 eligible animals were selected from 200 different dairy farms.

\footnotetext{
9 "Impact evaluation of anionic mineral mixture supplementation on milk production and the milk fever: a randomized control trial." AEA RCT Registry. April 17. https://doi.org/10.1257/rct.5108-2.0

${ }^{10} \mathrm{https} / / / \mathrm{www}$. indiastat.com/data/agriculture/milk-production/data-year/2019

${ }_{11}$ The $\mathrm{R}^{2}$ in final regression was around 0.7 .
} 
The AMM is aimed at reducing the MF in high yielding dairy animals. For this reason, we needed to work in areas where milk yield is high and the population of high yielding animals is large. The funding agency of the study has adopted 5 villages namely Samora, Garhi Gujran, Churni, Kamalpur Roran and Nagla Roran in the Karnal district of Haryana state in India. As Karnal is home for around 2.8 lakh high yielding (1.1 lakh exotic/crossbred cows and 1.8 lakh buffaloes) female bovines (Government of Haryana 2020), these villages were ideal for our experiment ${ }^{12}$. Data was collected from farmers who owned animals with high risk of MF incidence (animals in second or above parity with peak milk yield of more than $10 \mathrm{~kg}$ /day), which are not fed any type of anionic diets and had at least 1 month before parturition (calving) ${ }^{13}$. Baseline survey was conducted during September 2020 and the intervention (AMM) was supplemented to the treatment group during September-November 2020. The follow-up survey was done 2-3 months post-parturition between the last week of January and first week of February 2021.

\section{Intervention design}

On the demand side, a majority (77\%) of the farmers were aware of MF but weren't aware of the AMM. Only around 3\% (7 out of 214) of the farmers knew about AMM and only 1 farmer had used it earlier. Around half of the respondents report of taking precautionary measures against MF like

\footnotetext{
${ }^{12}$ The AMM was not supplemented to the animals in these villages; also, both the project staff and villagers were unaware of the product.

${ }^{13}$ Flow chart of the sampling plan is presented in Appendix 2.
} 
feeding calcium solutions, jaggery or combination of both post-partum (after calving). However, the use of preventive measures pre-partum (before calving) is absent in the sample villages. On the supply side, there is no availability of AMM in the villages or nearby sub-urban centers or in the district headquarters (which is around $20-25 \mathrm{~km}$ away from the village). This by default ensured that animals are not fed with any form of anionic diets satisfying the inclusion criterion.

The animals, after stratification (cows and buffaloes), were randomly assigned to treatment and control groups using the random number generator in Stata statistical package ${ }^{14}$. The intervention had two components; creating awareness and AMM supplementation. Creating awareness started right away from the baseline survey. All the farmers were given a brochure in local language (i.e., in Hindi) explaining the benefits of AMM, type of animals susceptible to MF and dosage, which they stuck on the walls of their farm. Also, subject matter specialists visited all the villages explaining the importance of MF prevention and how AMM helps to do it. The second and important component is AMM supplementation. AMM was supplemented to all the animals in the treatment group with specific instructions on how to use the product. The control group farmers were promised that they will also get AMM at a later date to avoid resentment against the institute. This is essential because the study is based on individual level randomization; treated and control farmers are neighbors

\footnotetext{
${ }^{14}$ https://dimewiki.worldbank.org/Randomization_in_Stata
} 
and the control farmers could attrite. Therefore, control farmers were taken into confidence before starting the intervention. After 60 days of parturition of treated animals, follow-up survey was undertaken and soon after, the control animals were also supplemented with AMM. Regular monitoring of treatment was done through field visits and telephonic conversations to confirm that AMM is supplemented to animals properly and in-time.

\section{DATA AND DESCRIPTIVE STATISTICS}

\section{Primary outcomes}

As specified in the pre-plan, this study has two primary outcomes; incidence of MF (1/0) and milk yield (kg/animal/day). These are selected based on the goals of AMM - reducing MF and increasing the milk yield.

Incidence of MF: Ca deficiency in high yielding bovines upon parturition leads to a condition called MF. It occurs usually within 72 hours of calving. The animals with MF express the following clinical signs. It will be unable to stand up and will be lying down, with its neck turned to one side and then laterally. In severe cases, animal becomes unconscious with sub-normal temperature and if left untreated, it will succumb (NDDB 2019). Farmers were asked if they observed these symptoms both at the baseline and followup. For analytical purposes, animals with clinical MF are coded 1 and zero otherwise. 
Milk yield (productivity): At the baseline and follow-up, we recorded the peak milk yield in the previous lactation. The peak milk yield was converted into average daily milk yield by using the standard conversion factor ${ }^{15}$. The unit of measurement is $\mathrm{kg} /$ animal/day.

\section{Secondary outcome}

Income from dairying: We estimate the net income from milk produced. The net income is calculated by subtracting variable costs (sum total of feed and fodder costs, veterinary costs like expenses on artificial insemination, vaccination and deworming, hired labor costs and MF treatment costs) from the value of milk produced (product of price of milk and total lactation milk production $\left.{ }^{16}\right)$. The unit of measurement is ₹/animal/lactation.

\section{Sample characteristics}

Table 1 presents the description of dependent variables, household characteristics, animal characteristics and feeding regime in the sample. In brief, dairying is the principal source of income for the sample farmers (67\%). Treatment and control group farmers own around 6 to 7 acres of land and 5 to 6 dairy animals. Control and treatment group farmers have a median education score of 4 and 5 respectively, implying they have attended school only upto secondary (9-10) and higher secondary (11-12) level.

\footnotetext{
${ }^{15}$ Average daily milk yield $=$ peak yield $\times \frac{200}{\text { lactation length }}$

${ }^{16}$ Lactation milk production $=$ average daily milk yield $\times$ lactation length
} 
Average daily milk yield in buffaloes and cows is around 8 and 10-11 $\mathrm{kg} /$ animal, respectively at the baseline. The peak milk yield in the present lactation is around 13 and $17 \mathrm{~kg} /$ animal. All the animals in the sample are on average in their $3^{\text {rd }}$ parity. The incidence of $\mathrm{MF}$ at the baseline is around $15 \%$ and $27 \%$ in cows and buffaloes, respectively. Net income per annum from dairying (net returns to variable costs) is higher for buffalo rearers (around ₹ 49,740/animal) than cow rearers (₹ 46,030/animal). The average variable cost is a little higher for crossbred cows than buffaloes. The price realized by farmers, as expected, was higher for buffalo milk (₹ $47 / \mathrm{kg})$ than cow milk (₹ $31 / \mathrm{kg})$. Although the prices realized by the treatment group farmers was significantly (slightly) higher (₹ $30.6 / \mathrm{kg}$ ) than control farmers (₹ $31.3 / \mathrm{kg}$ ), the value of milk sold was statistically similar. The summary of baseline characteristics reflects the inclusion criterions as we had selected higher parity animals with a peak milk yield of at least $10 \mathrm{~kg} /$ day.

The control variables used in our analysis include green fodder fed, dry fodder fed, concentrates fed and herd size. On an average, green fodder, dry fodder and concentrate fed per dairy animals is around 20-21 kg/day, 12 $\mathrm{kg} /$ day and $4 \mathrm{~kg} /$ day, respectively in the sample area. Control group cows are fed significantly higher green fodder than the treatment group cows.

\section{Balance}

Although statistical similarities in individual variables are achieved, sometimes the differences in treatment and control group characteristics 
might be in the same direction. This is an indication of the inability of the random assignment to generate two statistically similar groups. A solution is to complement Table 1 with a test for joint orthogonality (McKenzie 2015). Linear probability estimates of correlates of treatment status shows that the relationship between the treatment status and control as well as dependent variables are non-significant except for net income and variable costs incurred (at 10\% level) (Table 2). Joint test of orthogonality (F test) indicates that random assignment to two groups has succeeded in generating balance. Under pure randomization, if balance is achieved in observed variables we can expect to have balance in unmeasured/unobserved variables (Bruhn and McKenzie 2009). 
Cite as: Cariappa, A G Adeeth and Chandel, B S and Sankhala, Gopal and Mani, Veena and R, Sendhil and Dixit, Anil Kumar and Meena, B S, Prevention Is Better Than Cure: Experimental Evidence From Milk Fever Incidence in Dairy Animals of Haryana, India (May 23, 2021). DOI: $10.2139 /$ ssrn.3851561

Table 1 Baseline characteristics of sampling units and mean difference by treatment status

\begin{tabular}{|c|c|c|c|c|c|c|c|c|c|c|c|c|c|c|c|}
\hline \multirow{3}{*}{ Variables } & \multicolumn{5}{|c|}{ Buffalo $(n=100)$} & \multicolumn{5}{|c|}{$\operatorname{Cow}(n=100)$} & \multicolumn{5}{|c|}{ Overall $(n=200)$} \\
\hline & \multicolumn{2}{|c|}{$\begin{array}{l}\text { Control } \\
(\mathrm{n}=50)\end{array}$} & \multicolumn{2}{|c|}{$\begin{array}{l}\text { Treated } \\
(\mathrm{n}=50)\end{array}$} & \multirow{2}{*}{$\begin{array}{l}\text { Mean } \\
\text { Diff } \\
(\mathrm{C}-\mathrm{T})\end{array}$} & \multicolumn{2}{|c|}{$\begin{array}{l}\text { Control } \\
(\mathrm{n}=50)\end{array}$} & \multicolumn{2}{|c|}{$\begin{array}{l}\text { Treated } \\
(\mathrm{n}=50)\end{array}$} & \multirow{2}{*}{$\begin{array}{l}\text { Mean } \\
\text { Diff } \\
(\mathrm{C}-\mathrm{T})\end{array}$} & \multicolumn{2}{|c|}{$\begin{array}{l}\text { Control } \\
(\mathrm{n}=100)\end{array}$} & \multicolumn{2}{|c|}{$\begin{array}{l}\text { Treated } \\
(\mathrm{n}=100)\end{array}$} & \multirow{2}{*}{$\begin{array}{c}\text { Mean } \\
\text { Diff } \\
(\mathrm{C}-\mathrm{T})\end{array}$} \\
\hline & Mean & SD & Mean & SD & & Mean & SD & Mean & SD & & Mean & SD & Mean & SD & \\
\hline \multicolumn{16}{|l|}{ Panel A. Dependent variables } \\
\hline Average milk yield (kg/animal/day) & 7.80 & 1.94 & 7.86 & 2.82 & -0.06 & 10.19 & 3.84 & 10.72 & 4.57 & -0.53 & 8.99 & 2.45 & 9.29 & 4.25 & -0.30 \\
\hline Incidence of MF (1/0) & 0.18 & 0.37 & 0.12 & 0.26 & 0.06 & 0.28 & 0.44 & 0.26 & 0.35 & 0.02 & 0.23 & 0.32 & 0.19 & 0.40 & 0.04 \\
\hline Net income (000' ₹/animal/lactation) & 51.22 & 22.26 & 54.56 & 23.18 & -3.34 & 40.85 & 33.72 & 44.91 & 39.23 & -4.06 & 46.03 & 28.90 & 49.74 & 32.42 & -3.70 \\
\hline \multicolumn{16}{|l|}{ Panel B. Household characteristics } \\
\hline Experience in dairying (years) & 13.22 & 9.55 & 14.20 & 10.96 & -0.98 & 14.76 & 7.92 & 15.26 & 9.61 & -0.50 & 13.99 & 10.26 & 14.73 & 8.79 & -0.74 \\
\hline Education $(1-7)^{+}$ & 4.36 & 1.42 & 4.22 & 1.89 & 0.14 & 4.10 & 1.74 & 4.06 & 1.58 & 0.04 & 4.23 & 1.59 & 4.14 & 1.74 & 0.09 \\
\hline Household size (nos.) & 7.33 & 3.76 & 6.34 & 2.83 & 0.99 & 6.10 & 2.74 & 6.84 & 3.35 & -0.73 & 6.70 & 3.32 & 6.59 & 3.10 & 0.11 \\
\hline Training in dairying $(1 / 0)$ & 0.26 & 0.44 & 0.24 & 0.43 & 0.02 & 0.32 & 0.47 & 0.38 & 0.49 & -0.06 & 0.29 & 0.46 & 0.31 & 0.46 & -0.02 \\
\hline Principal income from dairying $(1 / 0)$ & 0.66 & 0.48 & 0.52 & 0.50 & 0.14 & 0.68 & 0.47 & 0.82 & 0.38 & -0.14 & 0.67 & 0.47 & 0.67 & 0.47 & 0.00 \\
\hline Land owned (acres) & 6.39 & 6.61 & 6.41 & 5.63 & -0.02 & 5.12 & 4.58 & 6.83 & 5.48 & $-1.71 *$ & 5.76 & 6.12 & 6.62 & 5.11 & -0.86 \\
\hline \multicolumn{16}{|l|}{ Panel C. Animal characteristics } \\
\hline Parity (nos.) & 2.64 & 0.80 & 2.80 & 0.81 & -0.16 & 2.80 & 1.03 & 2.80 & 0.90 & 0.00 & 2.72 & 0.81 & 2.80 & 0.97 & -0.08 \\
\hline $\begin{array}{l}\text { Peak milk yield in the previous } \\
\text { lactation (kg/animal/ day) }\end{array}$ & 11.89 & 2.95 & 11.98 & 4.30 & -0.09 & 15.54 & 5.86 & 16.35 & 7.02 & -0.81 & 13.72 & 3.74 & 14.17 & 6.51 & -0.45 \\
\hline $\begin{array}{l}\text { Peak milk yield in the present } \\
\text { lactation (kg/animal/ day) }\end{array}$ & 12.76 & 2.62 & 12.86 & 3.93 & -0.10 & 16.62 & 6.23 & 17.23 & 6.87 & -0.61 & 14.69 & 3.40 & 15.05 & 6.59 & -0.36 \\
\hline Herd size (nos.) & 6.24 & 3.18 & 6.30 & 2.82 & -0.06 & 4.60 & 2.95 & 5.10 & 2.56 & -0.50 & 5.42 & 3.00 & 5.70 & 2.77 & -0.28 \\
\hline \multicolumn{16}{|l|}{ Panel D. Feed and fodder fed } \\
\hline Green fodder fed (kg/animal/ day) & 21.65 & 6.58 & 20.49 & 6.30 & 1.16 & 20.27 & 6.17 & 17.68 & 4.59 & $2.59 * *$ & 20.96 & 6.45 & 19.09 & 5.58 & $1.87 * *$ \\
\hline Dry fodder fed (kg/animal/ day) & 12.32 & 3.76 & 12.85 & 5.14 & -0.53 & 10.71 & 4.11 & 12.03 & 4.90 & -1.32 & 11.52 & 4.50 & 12.44 & 4.56 & -0.93 \\
\hline Concentrate fed (kg/animal/ day) & 3.90 & 1.52 & 3.47 & 1.36 & 0.42 & 3.56 & 1.64 & 3.59 & 1.54 & -0.03 & 3.73 & 1.45 & 3.53 & 1.59 & 0.20 \\
\hline Mineral mixture fed (kg/animal/ day) & 0.03 & 0.04 & 0.02 & 0.04 & 0.00 & 0.02 & 0.03 & 0.03 & 0.04 & -0.01 & 0.03 & 0.04 & 0.03 & 0.04 & 0.00 \\
\hline Average variable cost ( $₹ /$ animal/ day) & 195.32 & 40.79 & 188.20 & 45.22 & 7.12 & 178.54 & 45.65 & 190.20 & 56.29 & -11.66 & 186.93 & 43.89 & 189.20 & 50.81 & -2.27 \\
\hline Milk price received (₹/kg) & 46.60 & 4.10 & 46.60 & 4.34 & 0.00 & 30.56 & 1.20 & 31.32 & 2.14 & $-0.76^{* *}$ & 38.58 & 8.60 & 38.96 & 8.40 & -0.38 \\
\hline Value of milk (000 ₹/animal/lactation) & 110.79 & 22.32 & 111.96 & 25.87 & -1.17 & 95.30 & 33.06 & 102.92 & 41.48 & -7.62 & 103.05 & 29.12 & 107.44 & $34 . .69$ & -4.39 \\
\hline Health score ${ }^{\#}$ & 3.60 & 0.67 & 3.48 & 0.86 & 0.12 & 3.74 & 0.69 & 3.80 & 0.53 & -0.06 & 3.67 & 0.77 & 3.64 & 0.62 & 0.03 \\
\hline
\end{tabular}


Cite as: Cariappa, A G Adeeth and Chandel, B S and Sankhala, Gopal and Mani, Veena and R, Sendhil and Dixit, Anil Kumar and Meena, B S, Prevention Is Better Than Cure: Experimental Evidence From Milk Fever Incidence in Dairy Animals of Haryana, India (May 23, 2021). DOI: $10.2139 /$ ssrn.3851561

Note: $* *$ and $*$ indicates statistical significance at $5 \%$ and $10 \%$, respectively

+ 1- Illiterate, 2-Primary (1-5), 3-Middle (6-8), 4-Secondary (9-10), 5-Higher secondary (11-12), 6-Diploma / certification, 7-Graduate and above.

\# Health score is an index computed by adding 4 dichotomous variables - artificial insemination (1/0), vaccination (1/0), deworming (1/0) and others (1/0). 
Cite as: Cariappa, A G Adeeth and Chandel, B S and Sankhala, Gopal and Mani, Veena and R, Sendhil and Dixit, Anil Kumar and Meena, B S, Prevention Is Better Than Cure: Experimental Evidence From Milk Fever Incidence in Dairy Animals of Haryana, India (May 23, 2021). DOI: $10.2139 /$ ssrn.3851561

Table 2 Balance test: Linear Probability Estimates

\begin{tabular}{|c|c|c|c|}
\hline Dependent variable: Treatment status (1/0) & $\begin{array}{c}\text { (1) } \\
\text { Buffalo }\end{array}$ & $\begin{array}{c}(2) \\
\text { Cow }\end{array}$ & $\begin{array}{c}(3) \\
\text { Overall }\end{array}$ \\
\hline Incidence of MF (1/0) & $\begin{array}{c}-0.131 \\
(0.164)\end{array}$ & $\begin{array}{c}-0.008 \\
(0.130)\end{array}$ & $\begin{array}{c}-0.064 \\
(0.096)\end{array}$ \\
\hline Average daily milk yield (kg/animal) & $\begin{array}{c}0.008 \\
(0.099)\end{array}$ & $\begin{array}{l}-0.132 \\
(0.077)\end{array}$ & $\begin{array}{c}0.002 \\
(0.020)\end{array}$ \\
\hline Net income (000’ ₹/animal/lactation) & $\begin{array}{c}0.000 \\
(0.000)\end{array}$ & $\begin{array}{l}0.000 * \\
(0.000)\end{array}$ & $\begin{array}{c}0.000 \\
(0.000)\end{array}$ \\
\hline Years of education of dairy farmer & $\begin{array}{c}0.008 \\
(0.048)\end{array}$ & $\begin{array}{c}-0.032 \\
(0.040)\end{array}$ & $\begin{array}{c}-0.021 \\
(0.029)\end{array}$ \\
\hline Years of experience in dairying & $\begin{array}{c}0.003 \\
(0.007)\end{array}$ & $\begin{array}{c}0.000 \\
(0.006)\end{array}$ & $\begin{array}{c}0.001 \\
(0.004)\end{array}$ \\
\hline Land holding (acres) & $\begin{array}{l}-0.001 \\
(0.010)\end{array}$ & $\begin{array}{c}0.019 \\
(0.013)\end{array}$ & $\begin{array}{c}0.008 \\
(0.008)\end{array}$ \\
\hline Herd size (nos.) & $\begin{array}{c}0.014 \\
(0.023)\end{array}$ & $\begin{array}{c}0.008 \\
(0.021)\end{array}$ & $\begin{array}{c}0.008 \\
(0.014)\end{array}$ \\
\hline Variable costs incurred (₹/animal/day) & $\begin{array}{l}-0.001 \\
(0.002)\end{array}$ & $\begin{array}{l}0.004 * \\
(0.002)\end{array}$ & $\begin{array}{c}0.000 \\
(0.001)\end{array}$ \\
\hline Training in dairying $(1 / 0)$ & $\begin{array}{c}0.006 \\
(0.143)\end{array}$ & $\begin{array}{c}0.089 \\
(0.149)\end{array}$ & $\begin{array}{c}0.061 \\
(0.095)\end{array}$ \\
\hline Health index of the animal & $\begin{array}{l}-0.043 \\
(0.082)\end{array}$ & $\begin{array}{c}0.060 \\
(0.093)\end{array}$ & $\begin{array}{c}0.021 \\
(0.062)\end{array}$ \\
\hline Extension (contact) index & $\begin{array}{c}0.009 \\
(0.070)\end{array}$ & $\begin{array}{l}-0.117 \\
(0.071)\end{array}$ & $\begin{array}{c}-0.057 \\
(0.049)\end{array}$ \\
\hline Constant term & $\begin{array}{c}0.604 \\
(0.503) \\
\end{array}$ & $\begin{array}{c}0.458 \\
(0.394) \\
\end{array}$ & $\begin{array}{c}0.427 \\
(0.301)\end{array}$ \\
\hline $\mathrm{N}$ & 100 & 100 & 200 \\
\hline $\mathrm{R}^{2}$ & 0.03 & 0.11 & 0.03 \\
\hline Joint test of orthogonality ( $F$ test) & 0.26 & 1.34 & 0.49 \\
\hline p-value & 0.99 & 0.22 & 0.91 \\
\hline
\end{tabular}

Note: $* p<0.1$. Standard errors in parenthesis.

\section{Attrition}

At the follow-up, a total of 5 animals ( 2 cows and 3 buffaloes) were sold by the farmers. Therefore, an attrition rate of $2.5 \%$ (5 out of 200 ) was found. These animals were replaced from the stock of 14 animals selected during the baseline survey. The balance was not affected by the replacement of animals.

\section{EMPIRICAL FRAMEWORK}

\section{Estimation strategy}


Linear probability model is used to estimate the effect of AMM on MF incidence. $\mathrm{Y}$ in Equation 1 is the binary variable with value 1 for $\mathrm{MF}$ incidence in follow-up and 0 otherwise. Control covariates $\left(X_{i}\right)$ used in the model include baseline MF incidence (1/0), daily milk yield $(\mathrm{kg} /$ animal) and parity of animals. $\gamma$ is the parameter of interest as it is the predicted probability of MF occurrence in the treated group in the follow-up.

$Y_{i}=\alpha+\gamma$ Treated $+\beta_{i} \cdot X_{i}+\varepsilon_{i}$

We use the Difference in Difference (DID) method to measure the effect of AMM on milk yield and farmer's income. We will compare the outcomes in pre-treatment (baseline) with post-treatment period (follow-up) for animals/households that was in the treatment group with animals/households in the control group.

In our main specification, we estimate the following equation:

$y_{i}=\beta_{0}+\beta_{1} \times$ period $_{i}+\beta_{2} \times$ treated $_{i}+\beta_{3} \times$ period $_{i} \times$ treated $_{i}+e_{i}$

$y_{i}=\beta_{0}+\beta_{1} \times$ period $_{i}+\beta_{2} \times$ treated $_{i}+\beta_{3} \times$ period $_{i} \times$ treated $_{i}+\beta_{4} \times X_{i}+e_{i} \ldots$ (3)

Our coefficient of interest is the interaction term between period (the posttreatment period dummy which takes the value of 1 for observations in follow-up in the main specification) and treated, an indicator of whether the households got the intervention in the post-treatment period. While $\beta_{1}$ measures the average change in outcome (milk yield/income) between the two time periods for both the treatment and control groups, $\beta_{2}$ accounts for the permanent difference in outcome between the two (treated and control) 
groups and can be interpreted as a treatment group specific effect. The coefficient of the interaction term, $\beta_{3}$, gives us our DID estimator or the treatment effect, i.e., the causal effect of AMM for the treated group, on outcome between baseline and follow-up, comparative to the control group. $X_{\mathrm{i}}$ is a vector of farmer and herd-level controls. These equations were estimated using STATA routine 'diff' (Villa 2016).

Identification Strategy

By the virtue of random assignment and the confirmation from the balance tests, the results are causally identified. Therefore, we estimate the causal effect of AMM (treatment) on milk fever incidence, milk productivity and farmer's income.

\section{RESULTS AND DISCUSSION}

\section{Impact of $A M M$}

Table 3 reports the impact of AMM on incidence of MF. As expected, the effect is negative and larger in cows. Overall, the probability of MF occurrence is $13-15$ percentage points lower in treated animals than the control animals. This implies that, if AMM is supplemented, the incidence of MF will reduce to $6-8 \%$ from $21 \%$ (incidence at baseline $=21 \%$ ). The reduction in MF will be higher in cows than the buffaloes. At the follow-up, in absolute terms, the incidence of $\mathrm{MF}$ reduced from $14 \%$ in control buffaloes and $22 \%$ in control cows to $2 \%$ in treated buffaloes and cows (Figure 1). 
Cite as: Cariappa, A G Adeeth and Chandel, B S and Sankhala, Gopal and Mani, Veena and R, Sendhil and Dixit, Anil Kumar and Meena, B S, Prevention Is Better Than Cure: Experimental Evidence From Milk Fever Incidence in Dairy Animals of Haryana, India (May 23, 2021). DOI: $10.2139 /$ ssrn.3851561

Table 3 Impact of AMM on incidence of MF

\begin{tabular}{|c|c|c|c|c|c|c|}
\hline Strata & \multicolumn{2}{|c|}{ Cow } & \multicolumn{2}{|c|}{ Buffalo } & \multicolumn{2}{|c|}{ Overall } \\
\hline Dependent variable in & & & Marginal & ects (dy) & & \\
\hline Estimator & LPM & Probit & LPM & Probit & LPM & Probit \\
\hline Dependent variable: & $-0.19 * * *$ & -0.19 & $-0.09 *$ & -0.08 & $-0.15 * * *$ & $-0.13 *$ \\
\hline Incidence of MF & $(0.05)$ & $(0.12)$ & $(0.05)$ & $(0.09)$ & $(0.04)$ & $(0.07)$ \\
\hline Incidence of MF in baseline & 0.27 & 0.27 & 0.15 & 0.15 & 0.21 & 0.21 \\
\hline No. of observations & 200 & 200 & 200 & 200 & 400 & 400 \\
\hline Controls? & Yes & Yes & Yes & Yes & Yes & Yes \\
\hline
\end{tabular}

Note: MF in proportion to total animals in the group.

Figures in parenthesis are Delta-method standard errors. $* p<0.10, * * * p<0.01$.

Marginal effects are estimated at treated $=1$ and period $=1$ (i.e., treatment group at the follow-up), thus are average treatment effects on treated (ATT).

Controls used in cow and buffalo strata - milk yield and lactation order; in overall model - milk yield, lactation order and type of animal (cow $=1$ and buffalo=0).

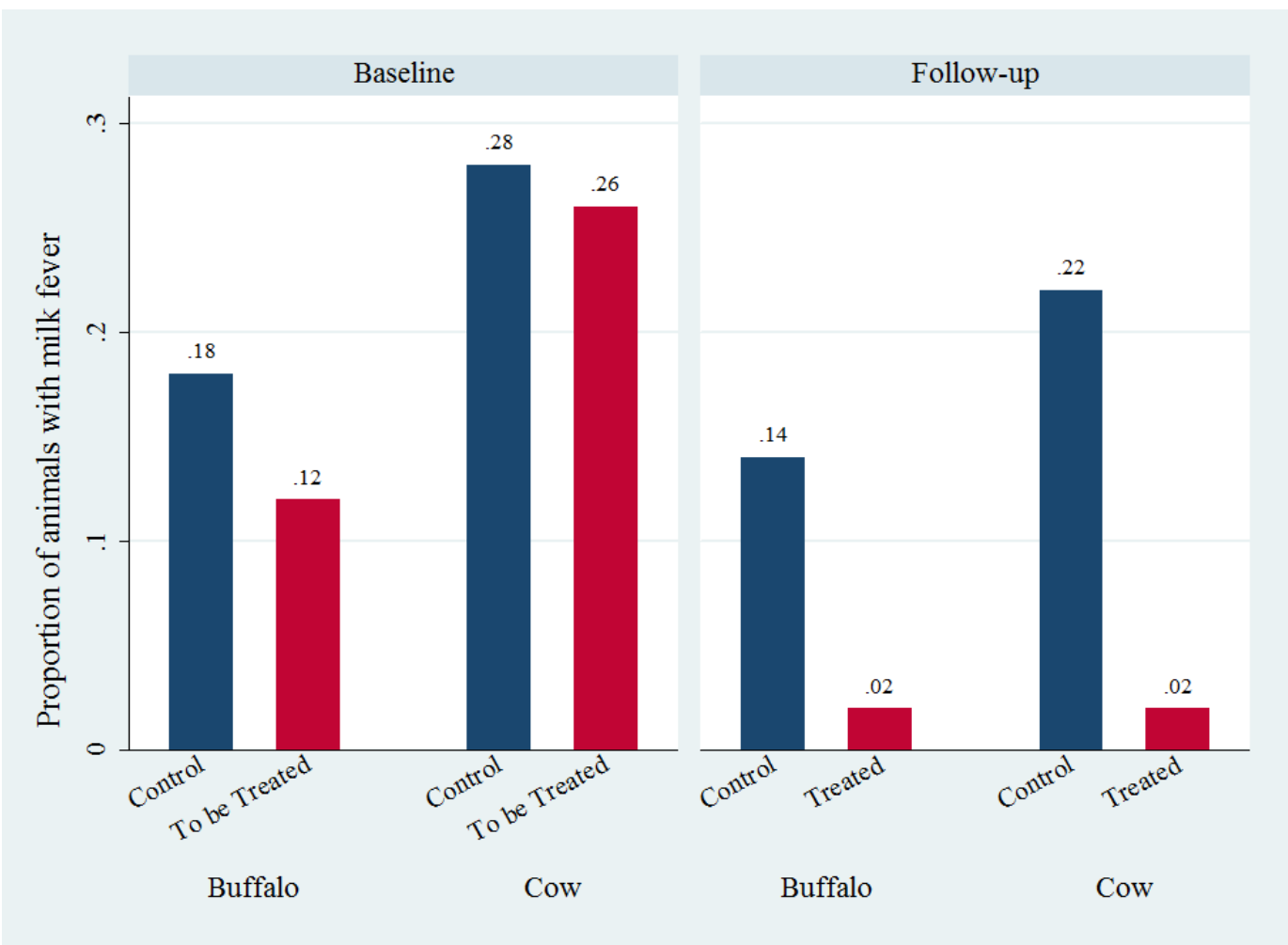

Figure 1 Impact of AMM on incidence of milk fever

The impact of AMM on daily average milk yield is presented in Table 4. AMM has a positive effect on milk yield, but the effect is statistically significant in the case of buffaloes and the overall sample. On an average, AMM supplementation increases milk yield by $10.6 \%$ and $14.57 \%$ in cows and buffaloes, respectively. Overall, the milk yield increases by $11.5 \%(10.472$ to 
Cite as: Cariappa, A G Adeeth and Chandel, B S and Sankhala, Gopal and Mani, Veena and R, Sendhil and Dixit, Anil Kumar and Meena, B S, Prevention Is Better Than Cure: Experimental Evidence From Milk Fever Incidence in Dairy Animals of Haryana, India (May 23, 2021). DOI: $10.2139 /$ ssrn.3851561

$11.929 \mathrm{~kg} /$ animal/day). To check whether the impact estimates are affected by extreme values (a fewer animals driving large differences in milk yield), we plot a kernel density function (Figure 2). Kolmogorov-Smirnov test confirms that the milk yield distribution of treated animals is significantly different than control animals ( $\mathrm{p}<0.01)$; implying that the increased milk yield is due to change across the distribution and not just few animals. Thus, the claim of AMM developers (that the milk yield will increase by $10 \%$ ) is confirmed by our study.

Table 4 Impact of AMM on milk yield

\begin{tabular}{|c|c|c|c|c|c|c|}
\hline Strata & \multicolumn{2}{|c|}{ Cow } & \multicolumn{2}{|c|}{ Buffalo } & \multicolumn{2}{|c|}{ Overall sample } \\
\hline Estimator & \multicolumn{6}{|c|}{ Difference-in-Differences (DID) } \\
\hline Dependent variable in & $\mathrm{kg} / \mathrm{animal} /$ day & $\begin{array}{c}\text { Natural } \\
\text { logarithm }\end{array}$ & $\mathrm{kg} / \mathrm{animal} / \mathrm{day}$ & $\begin{array}{c}\text { Natural } \\
\text { logarithm }\end{array}$ & kg/animal/day & $\begin{array}{c}\text { Natural } \\
\text { logarithm }\end{array}$ \\
\hline $\begin{array}{l}\text { Dependent variable: } \\
\text { Milk yield }\end{array}$ & $\begin{array}{c}1.319 \\
(1.100)\end{array}$ & $\begin{array}{c}0.106 \\
(0.086)\end{array}$ & $\begin{array}{l}1.173 * * * \\
(0.364)\end{array}$ & $\begin{array}{c}0.123 * * * \\
(0.044)\end{array}$ & $\begin{array}{l}1.457 * * \\
(0.563)\end{array}$ & $\begin{array}{l}0.115^{* *} \\
(0.048)\end{array}$ \\
\hline $\begin{array}{l}\text { Mean of Milk yield } \\
\text { in baseline }\end{array}$ & 10.456 & 2.292 & 7.823 & 2.039 & 10.472 & 2.307 \\
\hline No. of observations & 200 & 200 & 200 & 200 & 400 & 400 \\
\hline Controls? & Yes & Yes & Yes & Yes & Yes & Yes \\
\hline $\mathrm{R}^{2}$ & 0.19 & 0.22 & 0.40 & 0.38 & 0.30 & 0.33 \\
\hline \multicolumn{7}{|c|}{$\begin{array}{l}\text { \# Dependent variable in overall sample is } 3.5 \% \text { fat corrected milk }(\mathrm{FCM}) . \mathrm{FCM}=(0.35 \mathrm{x} \text { milk in } \mathrm{kg})+(18.57 \mathrm{x} \\
\text { fat in } \mathrm{kg}) \text {. }\end{array}$} \\
\hline $\begin{array}{l}\text { DID estimation of milk } \\
\mathrm{kg} / \text { animal/day) and pari } \\
\text { buffalo). }\end{array}$ & $\begin{array}{l}\text { yield included co } \\
y \text { of animals; and }\end{array}$ & variates gre & fodder fed, dry & fodder fed & nd concentrates & ed (all in \\
\hline
\end{tabular}

Our findings of increase in milk yield and decrease in $\mathrm{MF}$ incidence corroborate the findings of several experiments done in foreign settings (Lean et al. 2019; Santos et al. 2019; Melendez et al. 2019; Iwaniuk and Erdman 2015; Weich, Block and Litherland 2013). Now that the productivity of Indian dairy animals is on an increasing trend, the risk of $\mathrm{MF}$ is also continuously increasing (Appendix 3). This has important implications to the 
Cite as: Cariappa, A G Adeeth and Chandel, B S and Sankhala, Gopal and Mani, Veena and R, Sendhil and Dixit, Anil Kumar and Meena, B S, Prevention Is Better Than Cure: Experimental Evidence From Milk Fever Incidence in Dairy Animals of Haryana, India (May 23, 2021). DOI: $10.2139 /$ ssrn.3851561

welfare of the farmers; total economic losses (milk production loss + treatment costs + mortality losses) in the sample was estimated at ₹ 4320 (US\$ 59) per animal (Cariappa et al. 2021). Therefore, to prevent colossal losses due to MF, the use of AMM is thus recommended by this study.
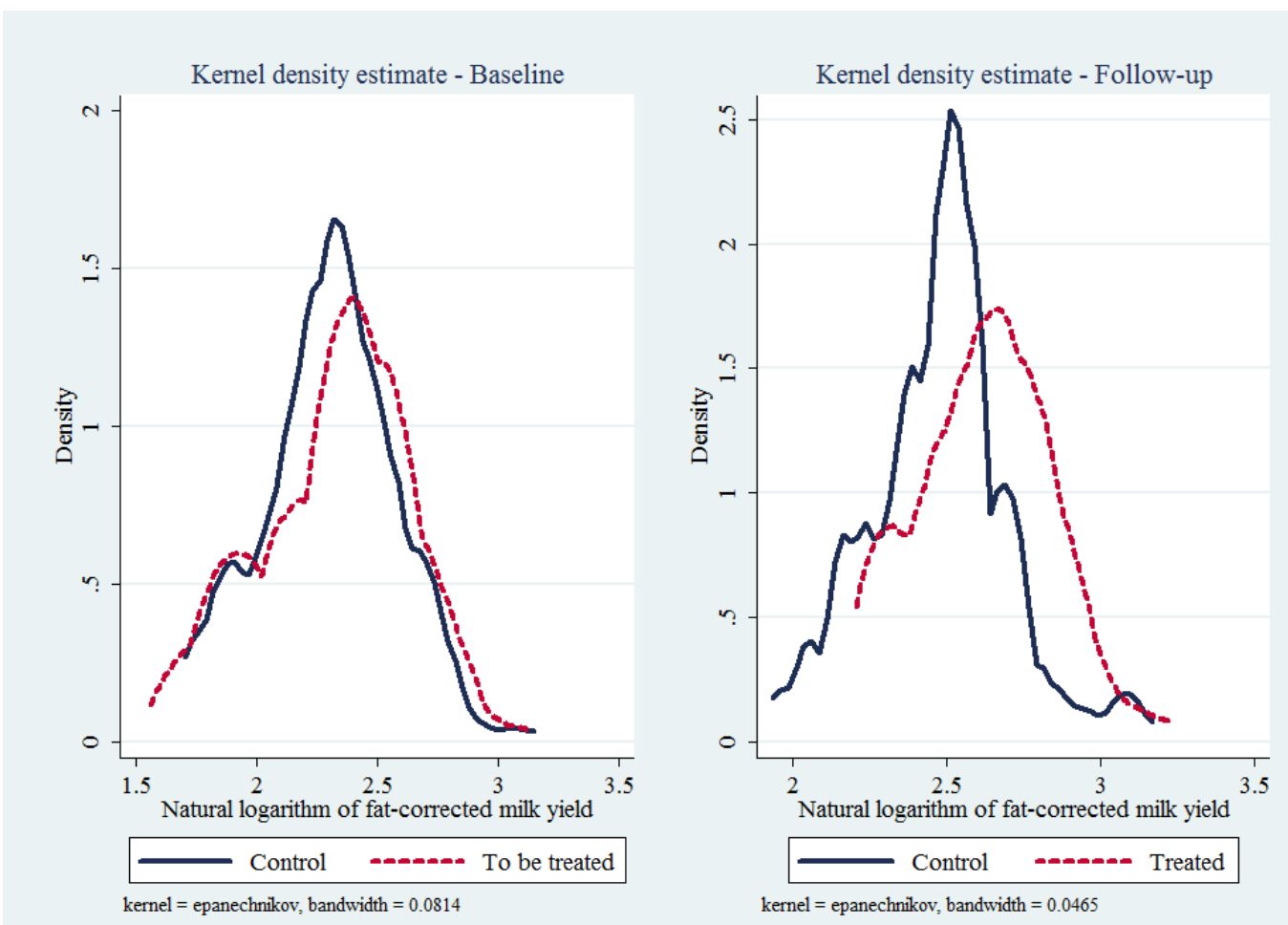

Note: Kolmogorov-Smirnov test statistics showed that the distribution of milk yield for treated and control animals differ at $1 \%$ level

\section{Figure 2 Distribution of 3.5\% fat-corrected milk yield in control and treated groups by period}

Impact of AMM on the secondary outcome (farmer's net income) is displayed in Table 5. We find that AMM supplementation leads to a significant increase in the income of the farmer. The impact is higher among buffalo rearers (significant ₹ 17,727 increase per animal per annum) than cow rearers $(₹ 14,666)$. In percentage terms, the increase in returns to variable 
Cite as: Cariappa, A G Adeeth and Chandel, B S and Sankhala, Gopal and Mani, Veena and R, Sendhil and Dixit, Anil Kumar and Meena, B S, Prevention Is Better Than Cure: Experimental Evidence From Milk Fever Incidence in Dairy Animals of Haryana, India (May 23, 2021). DOI: $10.2139 /$ ssrn.3851561

costs is highest in cow rearers than buffalo rearers with a $52.3 \%$ and $24.5 \%$ increase compared to the control group, respectively. Overall, farmer's income from dairying increased by ₹ 16,196 per animal per annum, which is a 38\% increase compared to the control group. Kolmogorov-Smirnov test for equality of income distributions rejects the null hypothesis of similar distributions of treated and control farmers (Figure 3). This implied that the increase in net income is contributed by all the farmers and not just by some well to do farmers.

Table 5 Impact of AMM on farmer's net income from dairying

\begin{tabular}{|c|c|c|c|c|c|c|}
\hline Strata & \multicolumn{2}{|c|}{ Cow } & \multicolumn{2}{|c|}{ Buffalo } & \multicolumn{2}{|c|}{ Overall } \\
\hline Estimator & \multicolumn{6}{|c|}{ Difference-in-Differences (DID) } \\
\hline Dependent variable in & $\begin{array}{l}\text { ₹/animal/ } \\
\text { lactation }\end{array}$ & $\begin{array}{c}\text { Natural } \\
\text { logarithm }\end{array}$ & $\begin{array}{l}\text { ₹/animal/ } \\
\text { lactation }\end{array}$ & $\begin{array}{c}\text { Natural } \\
\text { logarithm }\end{array}$ & $\begin{array}{l}\text { ₹/animal/ } \\
\text { lactation }\end{array}$ & $\begin{array}{c}\text { Natural } \\
\text { logarithm }\end{array}$ \\
\hline $\begin{array}{l}\text { Dependent variable: } \\
\text { Net income from dairying }\end{array}$ & $\begin{array}{l}14666 \\
(9192)\end{array}$ & $\begin{array}{l}0.523 * * \\
(0.262)\end{array}$ & $\begin{array}{l}17727 * * * \\
(5732)\end{array}$ & $\begin{array}{l}0.245^{* *} \\
(0.119)\end{array}$ & $\begin{array}{l}16196 * * * \\
(5657)\end{array}$ & $\begin{array}{l}0.380 * * \\
(0.149)\end{array}$ \\
\hline Mean of income in baseline & 42881 & 10.219 & 52888 & 10.758 & 47885 & 10.496 \\
\hline No. of observations & 200 & 195 & 200 & 200 & 400 & 395 \\
\hline Controls? & Yes & Yes & Yes & Yes & Yes & Yes \\
\hline R-squared & 0.42 & 0.37 & 0.48 & 0.43 & 0.37 & 0.33 \\
\hline
\end{tabular}

Note: Net income $=$ gross income - variable cost. Variable costs included are a sum total of expenses on green fodder, dry fodder, concentrates, hired labor including veterinary costs (artificial insemination, vaccination and deworming) and MF treatment costs.

Figures in parenthesis are robust standard errors.

Control covariates - parity and herd size (in nos.), green fodder fed, dry fodder fed and concentrates fed (all in $\mathrm{kg} / \mathrm{animal} / \mathrm{day}$ in linear models and its $\log$ values in $\log$ transformed models), health score, training on dairying $(1 / 0)$, experience, land holding, principal income from dairying (1/0) and extension score; and type of animal (1 - cow, 0 - buffalo) in overall equation.

$* * *$ and $* *$ indicates statistical significance at $1 \%$ and $5 \%$, respectively 

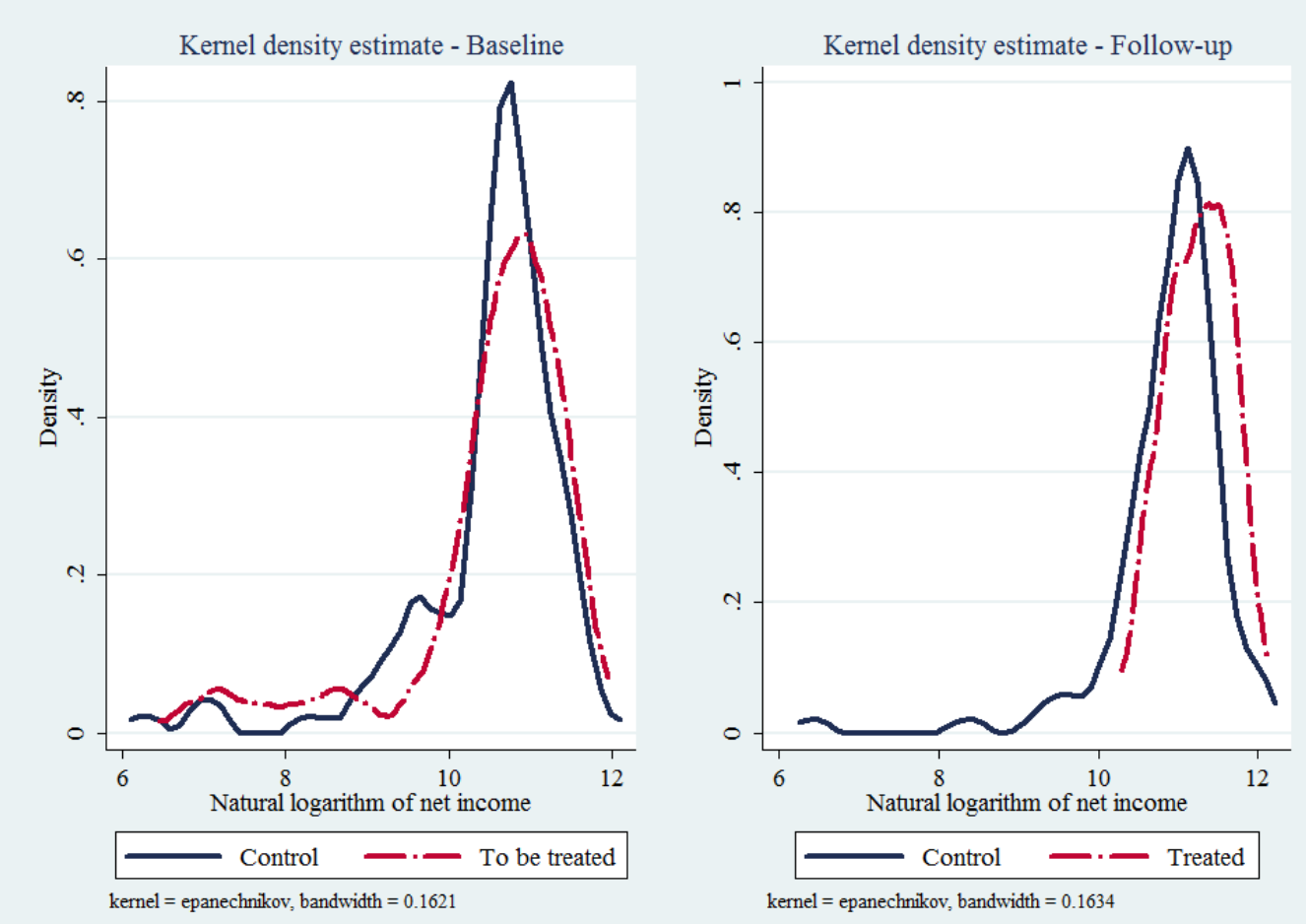

Note: Kolmogorov-Smirnov test statistics showed that the distribution of income for treated and control farmers differ at $1 \%$ level

Figure 3 Distribution of farmer's net income from milk in control and treated groups by period

Robustness of the impact estimates

Results of the robustness test of our impact estimates to alternative specifications are presented in Table 6. DID estimates show that AMM supplementation increased the milk yield by $1.457 \mathrm{~kg} /$ animal/day, i.e., an $11.5 \%$ increase compared to control animals (Table 3). Table 6, using different specifications (linear-linear, log-linear, linear-log and double log) in OLS estimator, reveals that milk yield increase ranges from 1.50 to 1.68 $\mathrm{kg} /$ animal/day and from $11.4 \%$ to $12.7 \%$. The range is close to the DID estimates and thus we conclude that our impact estimates are robust to alternative specifications. 
Cite as: Cariappa, A G Adeeth and Chandel, B S and Sankhala, Gopal and Mani, Veena and R, Sendhil and Dixit, Anil Kumar and Meena, B S, Prevention Is Better Than Cure: Experimental Evidence From Milk Fever Incidence in Dairy Animals of Haryana, India (May 23, 2021). DOI: $10.2139 /$ ssrn.3851561

Table 6 Robustness of the impact estimates to alternate specifications

\begin{tabular}{|c|c|c|c|c|}
\hline Dependent variable: FCM & (1) & (2) & (3) & (4) \\
\hline Estimator & \multicolumn{4}{|c|}{ Ordinary Least Squares (OLS) } \\
\hline Specification & Lin-lin & Log-lin & Lin-log & Log-log \\
\hline Treated $(1 / 0)$ & $\begin{array}{l}1.500 * * * \\
(0.246)\end{array}$ & $\begin{array}{l}0.114 * * * \\
(0.0184)\end{array}$ & $\begin{array}{l}1.683 * * * \\
(0.255)\end{array}$ & $\begin{array}{c}0.127 * * * \\
(0.0186)\end{array}$ \\
\hline $\mathrm{Y}_{\mathrm{t}-1}(\mathrm{FCM}$ in baseline $)$ & $\begin{array}{c}0.802 * * * \\
(0.0528)\end{array}$ & $\begin{array}{r}0.0572 * * * \\
(0.00347)\end{array}$ & & \\
\hline Green fodder fed (kg/animal/day) & $\begin{array}{l}-0.0132 \\
(0.0212)\end{array}$ & $\begin{array}{l}-0.00197 \\
(0.00156)\end{array}$ & & \\
\hline Dry fodder fed (kg/animal/day) & $\begin{array}{c}0.0142 \\
(0.0317)\end{array}$ & $\begin{array}{c}0.00138 \\
(0.00223)\end{array}$ & & \\
\hline Concentrates fed (kg/animal/day) & $\begin{array}{c}0.120 \\
(0.0937)\end{array}$ & $\begin{array}{c}0.00961 \\
(0.00653)\end{array}$ & & \\
\hline Parity (nos.) & $\begin{array}{l}-0.0246 \\
(0.165)\end{array}$ & $\begin{array}{r}-0.00414 \\
(0.0131)\end{array}$ & $\begin{array}{l}-0.0217 \\
(0.178)\end{array}$ & $\begin{array}{l}-0.00376 \\
(0.0137)\end{array}$ \\
\hline Animal ( 1 if cow and 0 if buffalo) & $\begin{array}{l}0.0246 \\
(0.292)\end{array}$ & $\begin{array}{l}-0.0392^{*} \\
(0.0204)\end{array}$ & $\begin{array}{c}0.338 \\
(0.353)\end{array}$ & $\begin{array}{l}-0.0130 \\
(0.0233)\end{array}$ \\
\hline $\operatorname{Ln} \mathrm{Y}_{\mathrm{t}-1}(\ln (\mathrm{FCM})$ in baseline $)$ & & & $\begin{array}{c}8.237 * * * \\
(0.680)\end{array}$ & $\begin{array}{l}0.602 * * * \\
(0.0426)\end{array}$ \\
\hline Green fodder fed $(\ln )$ & & & $\begin{array}{c}0.291 \\
(0.426)\end{array}$ & $\begin{array}{c}0.0000772 \\
(0.0313)\end{array}$ \\
\hline Dry fodder fed (ln) & & & $\begin{array}{l}-0.210 \\
(0.395)\end{array}$ & $\begin{array}{l}-0.00718 \\
(0.0249)\end{array}$ \\
\hline Concentrates fed (IHS) & & & $\begin{array}{l}0.622 * \\
(0.307)\end{array}$ & $\begin{array}{l}0.0491 * \\
(0.0221)\end{array}$ \\
\hline Constant term & $\begin{array}{c}3.620 * * * \\
(0.953)\end{array}$ & $\begin{array}{l}1.904 * * * \\
(0.0667)\end{array}$ & $\begin{array}{c}-8.455 * * * \\
(2.283)\end{array}$ & $\begin{array}{c}1.029 * * * \\
(0.149)\end{array}$ \\
\hline $\begin{array}{l}N \\
R^{2} \\
\end{array}$ & $\begin{array}{c}200 \\
0.699\end{array}$ & $\begin{array}{c}200 \\
0.702\end{array}$ & $\begin{array}{c}200 \\
0.673\end{array}$ & $\begin{array}{c}200 \\
0.698\end{array}$ \\
\hline
\end{tabular}

Note: Standard errors in parentheses. $* p<0.10, * * p<0.05, * * * p<0.01$

The impact of AMM ranged from $12.1 \%$ to $12.7 \%$ when the dependent variable was changed to absolute milk productivity (not fat-corrected).

\section{Limitations}

Purposive sampling of animals with high risk of MF (high yielding animals above $2^{\text {nd }}$ parity) might have led the incidence of $\mathrm{MF}$ in baseline to be on a higher side and thus leading to an overestimation of impact of AMM. The results are true only for the population similar to our sample and not universal. Therefore, a scale up of this successful pilot or a large cluster level randomized design is required to draw generalizable conclusions. 
In this study we evaluated the impact of the AMM, a preventive health product against MF in 200 dairy animals. We used a randomized controlled design to estimate the unbiased effects. It was found that the AMM supplementation led to a decrease in MF incidence from $21 \%$ in baseline to $2 \%$ in treated animals of follow-up. Overall probability of MF occurrence decreased by 13 percentage points in treated compared to control animals. Significant positive effect was found on milk yield and farmer's net income with $12 \%$ and $38 \%$ increase in treated compared to the control group, respectively.

The benefits of the preventive health product (AMM) are two-fold. First, it decreases the losses and improves animal health (by preventing MF incidence) and second is that it increases animal productivity and farmers' income. To illustrate the implications of these results we do a back of the envelope calculation. The total economic loss due to MF is ₹ 4,320 (US\$ 59) per animal (Cariappa et al. 2021). If AMM leads to a decrease in the MF incidence from $21 \%$ to $2 \%$, it helps to prevent losses upto ₹ 3,870 (US\$ 53). Additionally, AMM leads to a $1.5 \mathrm{~kg} /$ day increase in the level of milk production (Table 4). This leads to a significant increase in the farmer's net income to the tune of ₹ 16,196 (US\$222) per animal per annum (Table 5). Even if the market price of AMM (₹ 540 (US\$ 7.4) per animal) is subtracted, net gain stands at ₹ 15,656 (US\$ 215). Therefore we conclude that "Prevention of MF (+ ₹ 15,656) is better than cure (- ₹ 4,320)". Further 
Cite as: Cariappa, A G Adeeth and Chandel, B S and Sankhala, Gopal and Mani, Veena and R, Sendhil and Dixit, Anil Kumar and Meena, B S, Prevention Is Better Than Cure: Experimental Evidence From Milk Fever Incidence in Dairy Animals of Haryana, India (May 23, 2021). DOI: $10.2139 /$ ssrn.3851561

research building on this successful pilot is required to corroborate the results in different settings to draw generalizable conclusions.

\section{REFERENCES}

Barratt, A.S., M.H. Arnoult, B.V. Ahmadi, K.M. Rich, G.J. Gunn, and A.W. Stott. 2018. "A framework for estimating society's economic welfare following the introduction of an animal disease: The case of Johne's disease." PLoS ONE 13(8):1-26. Available at: https://doi.org/10.1371/journal.pone.0198436\%0AEditor:

Blanc, C.D., M. Van Der List, S.S. Aly, and H.A. Rossow. 2014. "Blood calcium dynamics after prophylactic treatment of subclinical hypocalcemia with oral or intravenous calcium." Journal of Dairy Science 97(11):6901-6906. Available at: http://dx.doi.org/10.3168/jds.2014-7927.

Block, E. 1984. "Manipulating Dietary Anions and Cations for Prepartum Dairy Cows to Reduce Incidence of Milk Fever." Journal of Dairy Science 67(12):29392948. Available at: http://dx.doi.org/10.3168/jds.S0022-0302(84)81657-4.

Boisvert, R.N., D. Kay, and C.G. Turvey. 2012. "Macroeconomic costs to large scale disruptions of food production: The case of foot- and-mouth disease in the United States.” Economic Modelling 29(5):1921-1930. Available at: http://dx.doi.org/10.1016/j.econmod.2012.06.007.

Bruhn, M., and D. McKenzie. 2009. "In pursuit of balance: Randomization in practice in development field experiments." American Economic Journal: Applied Economics 1(4):200-232. Available at: 10.1257/app.1.4.200.

Caixeta, L.S., P.A. Ospina, M.B. Capel, and D. V. Nydam. 2017. "Association between subclinical hypocalcemia in the first 3 days of lactation and reproductive performance of dairy cows." Theriogenology 94:1-7. Available at: http://dx.doi.org/10.1016/j.theriogenology.2017.01.039.

Cariappa, A.G.A., B.S. Chandel, G. Sankhala, V. Mani, R. Sendhil, A.K. Dixit, and B.S. Meena. 2021. "Estimation of economic losses due to milk fever and efficiency gains if prevented: evidence from Haryana, India.” SSRN Electronic 
Cite as: Cariappa, A G Adeeth and Chandel, B S and Sankhala, Gopal and Mani, Veena and R, Sendhil and Dixit, Anil Kumar and Meena, B S, Prevention Is Better Than Cure: Experimental Evidence From Milk Fever Incidence in Dairy Animals of Haryana, India (May 23, 2021). DOI: $10.2139 /$ ssrn.3851561

Journal. DOI: 10.2139/ssrn.3851567. Available at: https://arxiv.org/abs/2105.09782 [Accessed May 21, 2021].

Charbonneau, E., D. Pellerin, and G.R. Oetzel. 2006. "Impact of Lowering Dietary Cation-Anion Difference in Nonlactating Dairy Cows : A Meta-Analysis." Journal of Dairy Science 89(2):537-548. Available at: http:/ /dx.doi.org/10.3168/jds.S0022-0302(06)72116-6.

Chi, J., A. Weersink, J.A. Vanleeuwen, and G.P. Keefe. 2002. "The Economics of Controlling Infectious Diseases on Dairy Farms." Canadian Journal of Agricultural Economics 50:237-256.

Delaquis, A.M., and E. Block. 1995. "Dietary Cation-Anion Difference, Acid-Base Status, Mineral Metabolism, Renal Function, and Milk Production of Lactating Cows." Journal of Dairy Science 78(10):2259-2284.

Ender, F., I.W. Dishington, and A. Helgebostad. 1971. "Calcium Balance Studies in Dairy Cows under Experimental Induction and Prevention of Hypocalcaemic Paresis Puerperalis." Zeitschrift für Tierphysiologie Tierernährung und Futtermittelkunde 28:233-256.

Fadiga, M.L., and H.B. Katjiuongua. 2014. "Issues and strategies in ex-post evaluation of intervention against animal disease outbreaks and spread." Food Policy 49:418-424. Available at: http://dx.doi.org/10.1016/j.foodpol.2014.10.007.

Goff, J.P. 2008. "The monitoring, prevention, and treatment of milk fever and subclinical hypocalcemia in dairy cows." The Veterinary Journal 176(1):50-57. Available at: http://dx.doi.org/10.1016/j.tvj1.2007.12.020.

Gohin, A., and A. Rault. 2013. "Assessing the economic costs of a foot and mouth disease outbreak on Brittany : A dynamic computable general equilibrium analysis." Food Policy 39:97-107. Available at: http://dx.doi.org/10.1016/j.foodpol.2013.01.003.

Government of Haryana. 2020. "Handbook on 20th Livestock Census." Available at: http:// pashudhanharyana.gov.in/sites/default/files/documents/Livestock Census/Handbook on 20th Livestock Census.pdf. 
Cite as: Cariappa, A G Adeeth and Chandel, B S and Sankhala, Gopal and Mani, Veena and R, Sendhil and Dixit, Anil Kumar and Meena, B S, Prevention Is Better Than Cure: Experimental Evidence From Milk Fever Incidence in Dairy Animals of Haryana, India (May 23, 2021). DOI: $10.2139 /$ ssrn.3851561

Govindaraj, G., G.K. B, A. Krishnamohan, R. Hegde, N. Kumar, K. Sharma, A. Kanani, K. Natchimuthu, A. Pn, A.K. De, T. Ahmed, J. Misri, B.B. Dash, B. Pattnaik, and R. Habibur. 2021. "Foot and Mouth Disease (FMD) incidence in cattle and buffaloes and its associated farm-level economic costs in endemic India." Preventive Veterinary Medicine 190(August 2020):105318. Available at: https://doi.org/10.1016/j.prevetmed.2021.105318.

Govindaraj, G., P. Krishnamoorthy, K.R. Nethrayini, R. Shalini, and H. Rahman. 2017. "Epidemiological features and financial loss due to clinically diagnosed Haemorrhagic Septicemia in bovines in Karnataka, India.” Preventive Veterinary Medicine 144:123-133. Available at: http://dx.doi.org/10.1016/j.prevetmed.2017.05.027.

Hayer, S.S., K. VanderWaal, R. Ranjan, J.K. Biswal, S. Subramaniam, J.K. Mohapatra, G.K. Sharma, and M. Rout. 2017. "Foot-and-mouth disease virus transmission dynamics and persistence in a herd of vaccinated dairy cattle in India." (August).

Hennessy, D.A. 2007. "Behavioral Incentives, Equilibrium Endemic Disease, and Health Management Policy for Farmed Animals." American Journal of Agricultural Economics 89(3):698-711.

Hogeveen, H., W. Steeneveld, and C.A. Wolf. 2019. "Production Diseases Reduce the Efficiency of Dairy Production: A Review of the Results, Methods, and Approaches Regarding the Economics of Mastitis." Annual Review of Resource Economics 11:289-312. Available at:

https://www.annualreviews.org/doi/full/ 10.1146/annurev-resource-100518093954.

Iwaniuk, M.E., and R.A. Erdman. 2015. "Intake , milk production , ruminal , and feed efficiency responses to dietary cation-anion difference by lactating dairy cows." Journal of Dairy Science 98:8973-8985. Available at: http://dx.doi.org/10.3168/jds.2015-9949.

Jodlowski, M., A. Winter-Nelson, K. Baylis, and P.D. Goldsmith. 2016. "Milk in the Data: Food Security Impacts from a Livestock Field Experiment in Zambia." World Development 77:99-114. Available at: 
Cite as: Cariappa, A G Adeeth and Chandel, B S and Sankhala, Gopal and Mani, Veena and R, Sendhil and Dixit, Anil Kumar and Meena, B S, Prevention Is Better Than Cure: Experimental Evidence From Milk Fever Incidence in Dairy Animals of Haryana, India (May 23, 2021). DOI: $10.2139 /$ ssrn.3851561

http://dx.doi.org/10.1016/j.worlddev.2015.08.009.

Kimura, K., T.A. Reinhardt, and J.P. Goff. 2006. "Parturition and hypocalcemia blunts calcium signals in immune cells of dairy cattle." Journal of Dairy Science 89(7):2588-2595. Available at: http://dx.doi.org/10.3168/jds.S00220302(06)72335-9.

Krieger, M., S. Hoischen-Taubner, U. Emanuelson, I. Blanco-Penedo, M. de Joybert, J.E. Duval, K. Sjöström, P.J. Jones, and A. Sundrum. 2017. "Capturing systemic interrelationships by an impact analysis to help reduce production diseases in dairy farms." Agricultural Systems 153:43-52. Available at: http://dx.doi.org/10.1016/j.agsy.2017.01.022.

Lal, P., B.S. Chandel, A.K. Chauhan, and B. Kumari. 2020. "What determines the technical efficiency of dairy farmers in Sirsa cooperative milkshed ?" Indian Journal of Dairy Science 73(6):600-607.

Lean, I.J., P.J. DeGaris, D.M. McNeil, and E. Block. 2006. "Hypocalcemia in dairy cows: Meta-analysis and dietary cation anion difference theory revisited." Journal of Dairy Science 89(2):669-684. Available at: http://dx.doi.org/10.3168/jds.S0022-0302(06)72130-0.

Lean, I.J., J.E.P. Santos, E. Block, and H.M. Golder. 2019. "Effects of prepartum dietary cation-anion difference intake on production and health of dairy cows : A meta-analysis." Journal of Dairy Science (2014):1-31. Available at: http:/ /dx.doi.org/10.3168/jds.2018-14769.

McKenzie, D. 2015. "Tools of the Trade: a joint test of orthogonality when testing for balance." Development Impact Blog. Available at:

https://blogs.worldbank.org/impactevaluations / tools-trade-joint-testorthogonality-when-testing-balance [Accessed January 20, 2021].

Melendez, P., and S. Poock. 2017. "A Dairy Herd Case Investigation with Very Low Dietary Cation-Anion Difference in Prepartum Dairy Cows." Frontiers in Nutrition 4(26):1-6. Available at: https:/ / doi.org/10.3389/fnut.2017.00026.

Melendez, P., V. Zaror, P. Gaul, S.E. Poock, and J.P. Goff. 2019. "Effect of diets containing sulfate or chloride-based anionic salts, fed to grazing prepartum 
Cite as: Cariappa, A G Adeeth and Chandel, B S and Sankhala, Gopal and Mani, Veena and R, Sendhil and Dixit, Anil Kumar and Meena, B S, Prevention Is Better Than Cure: Experimental Evidence From Milk Fever Incidence in Dairy Animals of Haryana, India (May 23, 2021). DOI: $10.2139 /$ ssrn.3851561

dairy cows, on concentrations of $\mathrm{Ca}$ in plasma, disease incidence and milk yield." New Zealand Veterinary Journal 67(2):79-85.

NDDB. 2019. Handbook of Good Dairy Husbandry Practices. Anand, Gujarat: National Dairy Development Board. Available at: https://www.nddb.coop/sites/default/files/handbook_of_good_dairy_husband ry_practices_low.pdf.

Nilsson, P., M. Backman, L. Bjerke, and A. Maniriho. 2019. "One cow per poor family: Effects on the growth of consumption and crop production." World Development 114:1-12. Available at:

https://doi.org/10.1016/j.worlddev.2018.09.024.

Oetzel, G.R. 1991. "Meta-Analysis of Nutritional Risk Factors for Milk Fever in Dairy Cattle." Journal of Dairy Science 74(11):3900-3912. Available at: http://dx.doi.org/10.3168/jds.S0022-0302(91)78583-4.

Oetzel, G.R., and B.E. Miller. 2012. "Effect of oral calcium bolus supplementation on early-lactation health and milk yield in commercial dairy herds." Journal of Dairy Science 95(12):7051-7065. Available at: http://dx.doi.org/10.3168/jds.2012-5510.

Paul, D., B.S. Chandel, and J. Ray. 2013. "Quantity and Value of Milk Losses Due to Technical Constraints - A Case of Crossbred Cows in North-Eastern States of India." Indian Journal of Agricultural Economics 68(4):1-11. Available at: http:/ / ageconsearch.umn.edu/record/206355.

Ramos-Nieves, J.M., B.J. Thering, M.R. Waldron, P.W. Jardon, and T.R. Overton. 2009. "Effects of anion supplementation to low-potassium prepartum diets on macromineral status and performance of periparturient dairy cows." Journal of Dairy Science 92(11):5677-5691. Available at:

http:/ /dx.doi.org/10.3168/jds.2009-2378.

Reinhardt, T.A., J.D. Lippolis, B.J. Mccluskey, J.P. Goff, and R.L. Horst. 2011. "Prevalence of subclinical hypocalcemia in dairy herds." The Veterinary Journal 188(1):122-124. Available at: http://dx.doi.org/10.1016/j.tvj1.2010.03.025.

Rich, K.M., D. Roland-holst, and J. Otte. 2014. "An assessment of the ex-post 
Cite as: Cariappa, A G Adeeth and Chandel, B S and Sankhala, Gopal and Mani, Veena and R, Sendhil and Dixit, Anil Kumar and Meena, B S, Prevention Is Better Than Cure: Experimental Evidence From Milk Fever Incidence in Dairy Animals of Haryana, India (May 23, 2021). DOI: $10.2139 /$ ssrn.3851561

socio-economic impacts of global rinderpest eradication : Methodological issues and applications to rinderpest control programs in Chad and India." Food Policy 44:248-261. Available at:

http://dx.doi.org/10.1016/j.foodpol.2013.09.018.

Rich, K.M., and A. Winter-Nelson. 2007. "An integrated epidemiological-economic analysis of foot and mouth disease: Applications to the southern cone of South America." American Journal of Agricultural Economics 89(3):682-697. Available at: $10.1111 / \mathrm{j} .1467-8276.2007 .01006 . x$.

Rodríguez, E.M., A. Arís, and A. Bach. 2017. "Associations between subclinical hypocalcemia and postparturient diseases in dairy cows." Journal of Dairy Science 100(9):7427-7434. Available at: http://dx.doi.org/10.3168/jds.201612210.

Santos, J.E.P., I.J. Lean, H. Golder, and E. Block. 2019. "Meta-analysis of the effects of prepartum dietary cation-anion difference on performance and health of dairy cows." Journal of Dairy Science:1-21. Available at:

http://dx.doi.org/10.3168/jds.2018-14628.

Schroeder, T.C., D.L. Pendell, M.W. Sanderson, and S. McReynolds. 2015.

"Economic Impact of Alternative FMD Emergency Vaccination Strategies in the Midwestern United States." Journal of Agricultural and Applied Economics 47(1):47-76. Available at: 10.1017/aae.2014.5.

Sok, J., and E.A.J. Fischer. 2020. "Farmers' heterogeneous motives, voluntary vaccination and disease spread: An agent-based model." European Review of Agricultural Economics 47(3):1201-1222. Available at: https://doi.org/10.1093/erae/jbz041.

Thakur, R., P.K. Dogra, V. Sankhyan, and P. Sood. 2017. "Anionic Mishran Supplementation to Check Incidence of Milk Fever." Journal of Animal Research 7(2):405-408. Available at: 10.5958/2277-940X.2017.00058.4.

Thirunavukkarasu, M., G. Kathiravan, A. Kalaikannan, and W. Jebarani. 2010. "Quantifying Economic Losses due to Milk Fever in Dairy Farms." Agricultural Economics Research Review 23(1):77-81. Available at: 
Cite as: Cariappa, A G Adeeth and Chandel, B S and Sankhala, Gopal and Mani, Veena and R, Sendhil and Dixit, Anil Kumar and Meena, B S, Prevention Is Better Than Cure: Experimental Evidence From Milk Fever Incidence in Dairy Animals of Haryana, India (May 23, 2021). DOI: $10.2139 /$ ssrn.3851561

http://ageconsearch.umn.edu/record/92097.

Villa, J.M. 2016. "diff: Simplifying the estimation of difference-in-differences treatment effects." Stata Journal 16(1):52-71. Available at: https://doi.org/10.1177/1536867X1601600108.

Wang, T., and D.A. Hennessy. 2014. "Modelling interdependent participation incentives: Dynamics of a voluntary livestock disease control programme." European Review of Agricultural Economics 41(4):681-706. Available at: https://doi.org/10.1093/erae/jbt038.

Wang, T., and D.A. Hennessy. 2015. "Strategic Interactions Among Private and Public Efforts When Preventing and Stamping Out a Highly Infectious Animal Disease." American Journal of Agricultural Economics:1-17. Available at: https://doi.org/10.1093/ajae/aau119.

Weich, W., E. Block, and N.B. Litherland. 2013. "Extended negative dietary cationanion difference feeding does not negatively affect postpartum performance of multiparous dairy cows." Journal of Dairy Science 96(9):5780-5792. Available at: http://dx.doi.org/10.3168/jds.2012-6479.

\section{APPENDIX}


Cite as: Cariappa, A G Adeeth and Chandel, B S and Sankhala, Gopal and Mani, Veena and R, Sendhil and Dixit, Anil Kumar and Meena, B S, Prevention Is Better Than Cure: Experimental Evidence From Milk Fever Incidence in Dairy Animals of Haryana, India (May 23, 2021). DOI: $10.2139 /$ ssrn.3851561

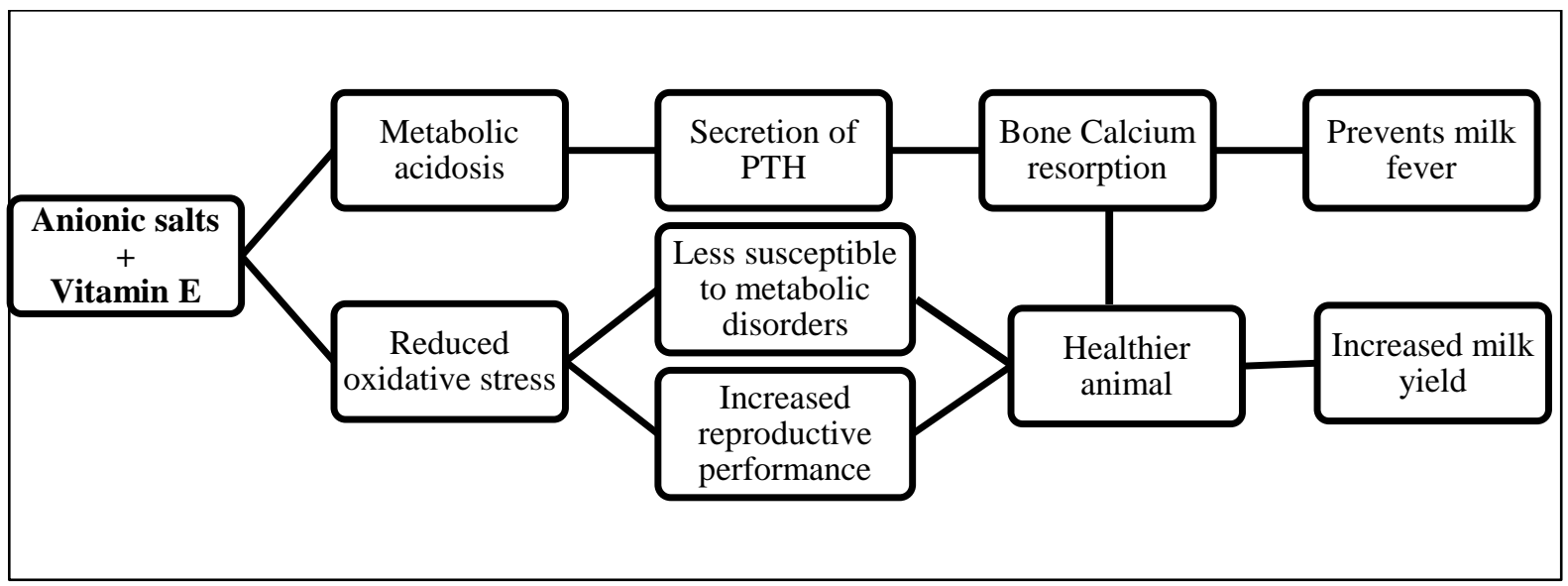

Appendix 1 How AMM causes MF prevention and increased milk yield

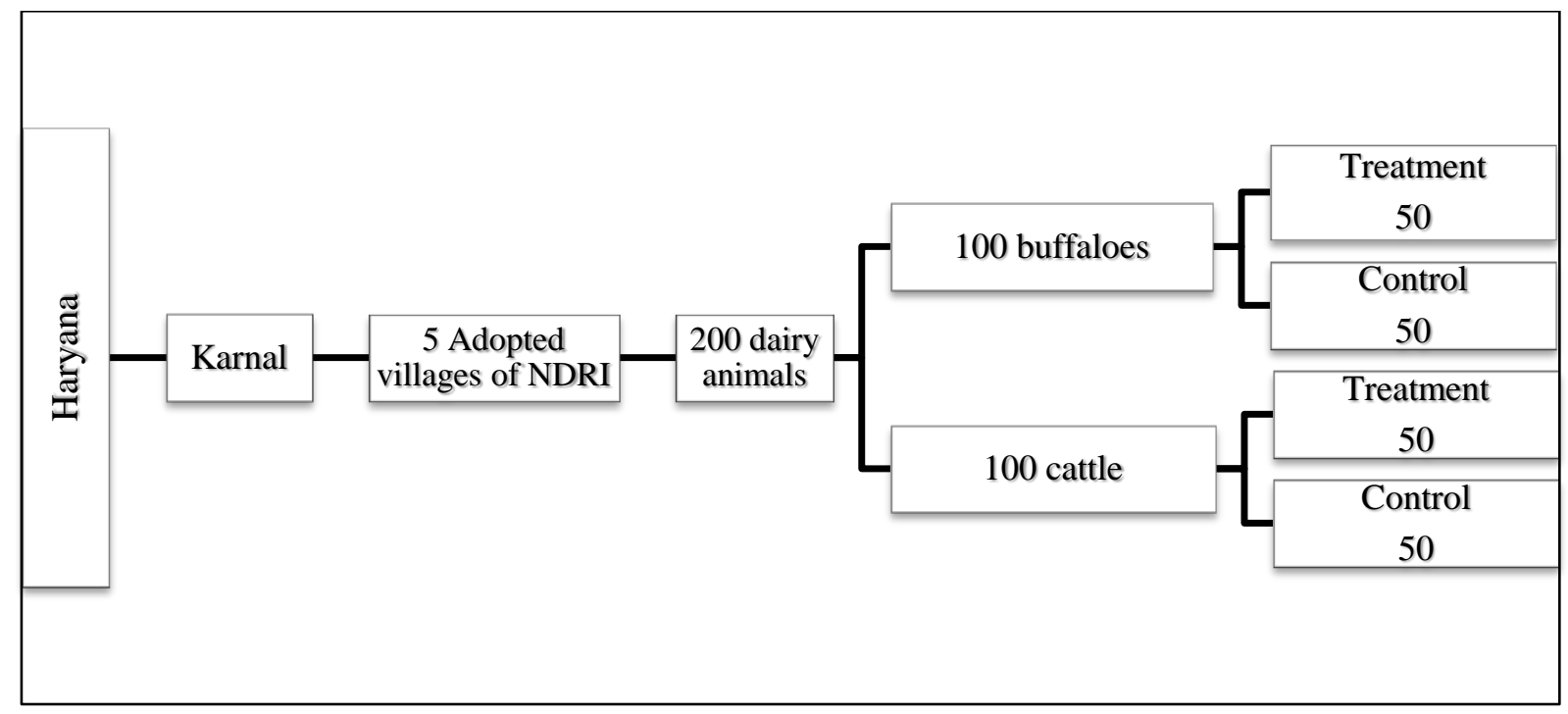

Appendix 2 Sampling plan of the study 
Cite as: Cariappa, A G Adeeth and Chandel, B S and Sankhala, Gopal and Mani, Veena and R, Sendhil and Dixit, Anil Kumar and Meena, B S, Prevention Is Better Than Cure: Experimental Evidence From Milk Fever Incidence in Dairy Animals of Haryana, India (May 23, 2021). DOI: $10.2139 /$ ssrn.3851561

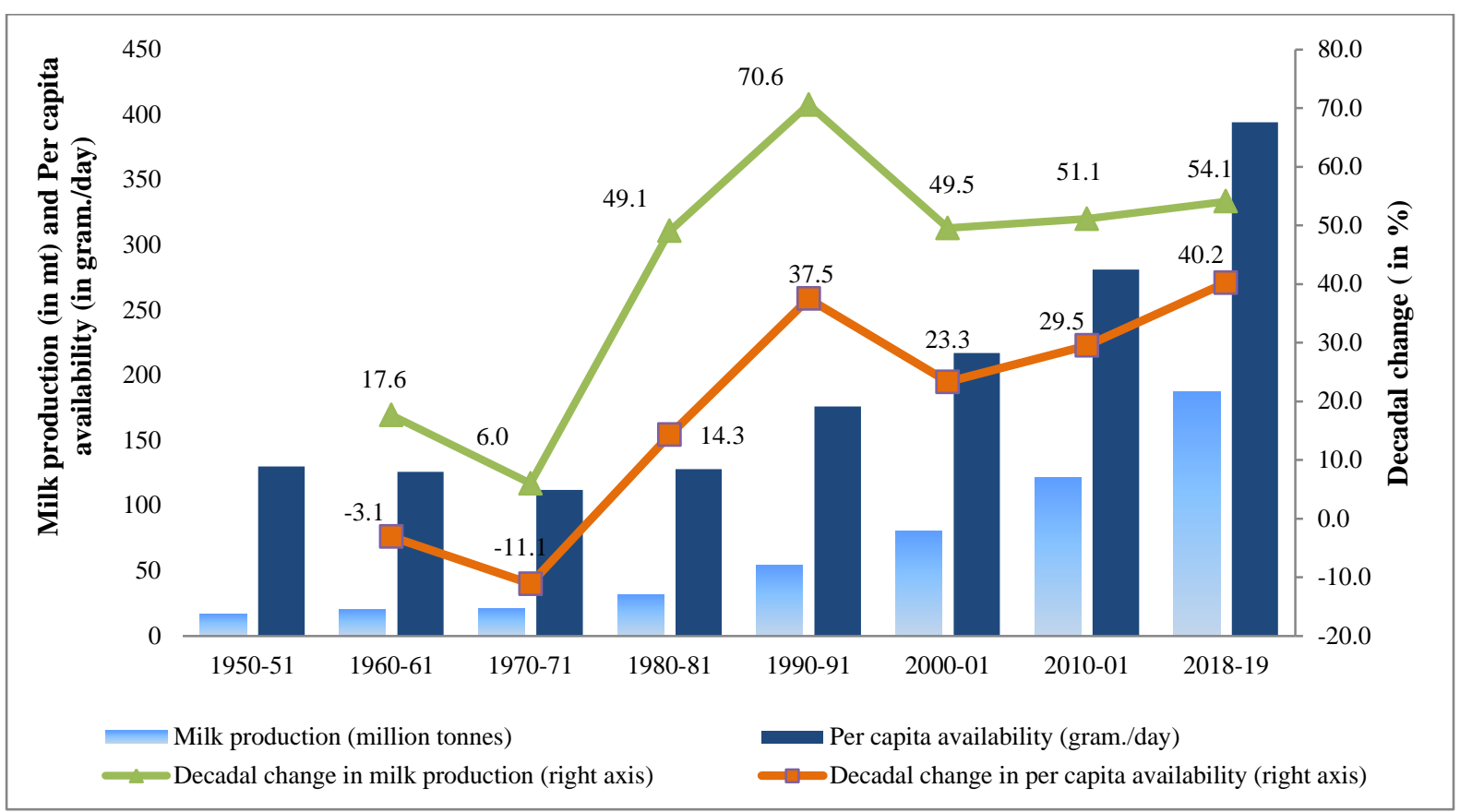

Source: Basic Animal Husbandry Statistics, 2019

(http://dahd.gov.in/sites/default/filess/BAHS\%20\%28Basic\%20Animal\%20Husbandry\%2 OStatistics-2019\%29_1.pdf)

Appendix 3 Milk production in India (1950-2018) 